УДК 111.32:316.7

А. В. Пашинська, аспірантка

\title{
РОЛЬ СОЦІОКУЛЬТУРНОГО ПРОСТОРУ У ФОРМУВАННІ СТІЙКОСТІ САМОІДЕНТИЧНОСТІ ЛЮДИНИ
}

\begin{abstract}
Актуальність теми дослідження. Програма сталого розвитку світу потребує фрілософьського дослідження сталого розвитку окремої людини.

Постановка проблеми. Оскільки ми живемо в демократичному суспільстві, то сталий розвиток цього суспільства можливий за умови бажання досягти цілей сталого розвитку світу, зокрема власного сталого розвитку кожного члена цього суспільства.

Аналіз останніх досліджень і публікацій. Більшість праць присвячено економічному, екологічному чи соціальному аналізу сталого розвитку: Adamiak S., Blewitt J., James P., Richard C., Sachs J. D., Walczak D., Баринова B.A., Белотелов H. В., Бех В. П., Біляцький С., Бобух І., Бочковська А., Бродский Ю. І., Ватченко О. Б., Гребенніков В. О., Денисюк С. П., Жарова Л. В., Земцов С.П., Кащеєва Г. М., Ключко В. Г., Лященко І. С., Миркин Б. М., Наумова Л. Г., Нерсесян Г. А., Оленев Н. Н., Онегіна В. М., Павловський Ю. Н., Тарасова Н. П. Проблема сталого розвитку людини в фрілософрському дискурсі досліджена недостатньо.
\end{abstract}

Виділення недосліджених частин загальної проблеми. Питання, що лежить в основі сталого розвитку людини потребує більш розгорнутого дослідження саме в фрілософрському контексті.

Постановка завдання. Дослідження сталого розвитку людини потребує аналізу процесу формування стійкості самоідентичності людини та визначення ролі соціокультурного простору в цьому процесі.

Виклад основного матеріалу. У статті розглядається стійкість самоідентичності людини як основа ії сталого розвитку. Внутрішня та зовнішня культура людини визначаються як основні інструменти набуття стійкості самоідентичності. Зазначається, що соціокультурний простір людини є середовищем розвитку ї̈ зовнішньої культури й відіграє важливу роль для ствердження людини у стійкості самоідентичності та особистого сталого розвитку.

Висновки. Використання певних практик соціокультурного простору здатне допомогти людині розвинути зовнішню культуру й досягти особистого сталого розвитку. Необхідне дослідження шляхів залучення людини з стійкість самоідентичності до соціокультурного простору й виявлення найбільш ефрективних практик розвитку зовнішньої культури людини.

Ключові слова: сталий розвиток; соціокультурний простір; стійкість самоідентичності; культура.

A. V. Pashynska, Postgraduate Student

\section{THE ROLE OF SOCIOCULTURAL SPACE IN THE FORMATION OF SUSTAINABLE SELF-IDENTITY}

Urgency of the research. The program of sustainable development of the world requires a philosophical study of sustainable development of the individual.

Target setting. Since we live in a democratic society, the sustainable development of this society is possible only if each member of this society will be willing to achieve the goals of sustainable development of the world, the own sustainable development, in particular.

Actual scientific researches and issues analysis. Most of the researches are devoted to economic, ecological or social analysis of sustainable development (Adamiak S., Blewitt J., James P., Richard C., Sachs J.D., Walczak D., Barinova V. A., Belotelov N. V., Bekh V. P., Bilyatsky S., Bobukh I., Bochkovskaya A., Brodsky Yu. I., Vatchenko O. B., Grebennikov V. O., Denisyuk S. P., Zharova L. V., Zemtsov S. P., Kashcheeva G. M., Klyuchko V. G., Lyashchenko I. S., Mirkin B. M., Naumova L. G., Nersesyan G. A., Olenev N. N., Onegina V. M., Pavlovsky Yu. N., Tarasova N. P.). The problem of sustainable human development in philosophical discourse is insufficiently studied. 
Uninvestigated parts of general matters defining. The issue about the base of sustainable human development requires more detailed research in the philosophical context.

The research objective. The study of sustainable human development requires an analysis of the process of forming the sustainable self-identity and determining the role of sociocultural space in this process.

The statement of basic materials. The article considers the sustainable self-identity as the base of human sustainable development. Internal and external human culture are defined as the main tools for gaining sustainable self-identity. It is noted that the sociocultural space of man is the environment for the development of their external culture and plays an important role in the assertion of man in the sustainable self-identity and personal sustainable development.

Conclusions. The use of certain practices of sociocultural space can help a person to develop an external culture and achieve personal sustainable development. It is necessary to study the ways of involving a person with the sustainable self-identity in the sociocultural space and to identify the most effective practices for the development of external human culture.

Keyword: sustainable development; sociocultural space; sustainable self-identity; culture.

DOI: 10.25140/2412-1185-2019-2(14)-71-76

Актуальність теми дослідження. В 80-х роках 20 століття зародилася парадигма сталого розвитку світу, дотримання якої ряд вчених визнали завданням 3 тисячоліття. Автором концепту "сталий розвиток" прийнято вважати Ґермана Дейлі, який системно розкрив це поняття в його роботах [1].

Вчений вважав, що «"сталість" $є$ одним з таких складних абстрактних іменників як істина, краса, справедливість. Краще говорити про них не абстрактно, а, наприклад сказати: «Я думаю, що за підпалення дому Сміта, Джон має сидіти в тюрмі п'ять років» Зміст такого речення здається нам цілком справедливим. Так, що не виникає потреби у абстрактному визначенні суті справедливості. Аналогічно, замість абстрактного визначення поняття «сталість», краще розглянути його як прикметник - тоді ми повинні визначити щось, що $є$ сталим. А ще краще використати допоміжне дієслово - «підтримувати»» [1]. Далі Ґ. Дейлі конкретизував, що слід підтримувати економіку й біосферу та запропонував своє бачення цієї підтримки.

Ідеї вченого мали значний вплив на світову спільноту й набули подальшого розвитку, кульмінацією якого можна вважати Резолюцію Генеральної Асамблеї ООН, затверджену 25 вересня 2015 року, в якій були визначені Цілі сталого розвитку світу до 2030 року [2]. Таким чином концепт «сталий розвиток» увійшов в економічний, політичний і соціокультурний простір багатьох країн світу й зараз активно досліджується.

В центрі уваги цих досліджень - економіка, екологія чи соціум, оскільки традиційно сталий розвиток розглядають як гармонійний розвиток цих трьох структурних підсистем [3, с. 165]. Разом з тим сталий чи стійкий розвиток людини досліджений недостатньо.

Постановка проблеми. Ми живемо в демократичному суспільстві, що передбачає управління в країні «знизу до гори» [4]. Таким чином, повна реалізація цілей сталого розвитку можлива за умови волі «знизу», тобто бажання кожної людини досягти цих цілей, а насамперед власного сталого розвитку.

Отже, в чому суть сталого розвитку людини? Аристотель вважав, що призначення держави допомагати людям бути доброчесними. Відповідно, люди мають розвивати власну доброчесність задля державного блага, яке полягає у загальному щасті.

Таким чином, кожна людина має прагнути реалізувати цілі сталого розвитку, а держава допомагати в цьому. Однак, сучасна людина залишається багатопартійною й народною в гіршому сенсі цих слів, коли особиста безвідповідальність приховується за плечима широких народних мас [5, с. 7]. В. Малахов стверджує, що «з посиленням партійності, ідеології й орієнтації на маси майже губиться власне етична позиція, пов'язана з повагою до реальності, усвідомленням непорушності моральних цінностей, незамінності й серйозності життєвого покликання кожної особи, - позиція "самостояння" вільної людини у світі. Не дивно, що коли свобода нарешті прийшла й коли від власного вибору й власної гідності людей стало залежати більше, ніж раніше, - одразу далася в знаки страхітлива нестача цих засад» [5, с. 7]. 
Так, замість людяності поступово встановлюється трансгуманізм, людина потрапляє в полон кліпової культури. Тож необхідна мужність людяності для змоги розпізнавати засоби масової маніпуляції власною свідомістю та не піддаватися їм; бути Людиною, а не візуальним клоном чи одиницею біомаси; поводитися людяно з іншими, долати відчуження.

Щоб розвинути таку людяність В. Малахов закликає бути собою: «Чого не вистачає для надання духовному відродженню глибокого, необоротного характеру? Коротко кажучи насамперед нашої здатності бути самими собою. Того самого етичного "самостояння"» - пише філософ [5,c. 9]. Погоджуючись з цими ідеями мислителя, ми вважаємо, що щоб бути собою, треба спочатку стати собою - Людиною.

Отже, сталий розвиток соціуму можливий за умови сталого розвитку кожної окремої людини. Ми припускаємо, що в основі такого розвитку - стійкість самоідентичності людини.

Аналіз останніх досліджень і публікацій. Ідея сталого розвитку не нова, про гармонійний розвиток суспільства писали: Платон, Макіавеллі Н., Мор Т., Маркс К., Енгельс Ф., Ленін В. І., Вебер М., Руссо Ж-Ж., Тофлер Е., Маркузе Г., Вернадський В. І. та багато інших.

Також багато сучасних вчених досліджували проблеми сталого розвитку, серед них: Adamiak S., Blewitt J., James P., Richard C., Sachs J. D., Walczak D., Баринова В. А., Белотелов Н. В., Бех В. П., Біляцький С., Бобух І., Бочковська А., Бродский Ю. І., Ватченко О. Б., Гребенніков В. О., Денисюк С. П., Жарова Л. В., Земцов С.П., Кащеєва Г. М., Ключко В. Г., Лященко І. С., Миркин Б. М., Наумова Л. Г., Нерсесян Г. А., Оленев Н. Н., Онегіна В. М., Павловський Ю. Н., Тарасова Н. П.

Про ідентичність в контексті сталого розвитку йдеться в роботах: Dobers P., Hay R., Hurth V., Niinimäki K., Soron D., Strannegård L., Белінская Е. П., Гукалова І. В., Конопак I. А., Кубриченко Т. В., Кузьмин М. Ю.

Ряд вчених досліджували ідентичність в контексті соціокультурного простору: Vivian L., Клочко В. Є., Лук'янов О. В., Кривопусков В.В., Кочетов М. Н. Теремко В. І.

Однак, переважна більшість досліджень ідентичності зроблені з психології або зосереджені на фрормуванні національної ідентичності.

Виділення недосліджених частин загальної проблеми. В фрілософрському дискурсі досліджень сталого розвитку людини недостатньо. Зокрема мало розроблена проблематика формування стійкості самоідентичності людини.

Оскільки світ постійно глобалізується, й відбувається синтез культур, то вважаємо суттєвим дослідити роль соціокультурного простору у становленні стійкості самоідентичності людини. Для досягнення цієї мети, спробуємо вирішити такі завдання: 1) розділити поняття «сталий» й «стійкий» в контексті самоідентичності; 2) розрізнити внутрішню й зовнішню культури людини; 3) дослідити вплив соціокультурного простору на культуру людини в контексті сталого розвитку людини.

Виклад основного матеріалу. Англійське "sustainable development” зазвичай перекладають як “сталий розвиток”. Такий переклад допустимий, коли йдеться про економічний розвиток. Втім в контексті самоідентичності людини, краще вживати “стійкий розвиток" або коротше i змістовніше - “стійкість”. Адже тлумачать: «сталий - 1) який не змінюється, зберігає той самий склад, розмір, однакову форму, величину тощо; незмінний, постійний; який не зазнає коливань, не піддається змінам; стійкий; урівноважений (про вдачу). Стала рівновага - рівновага, в якій тіло перебуває під дією рівних між собою протилежно спрямованих сил; 2) постійна, незмінна величина серед тих, які змінюються; 3) який не припиняється, не переривається, триває весь час; безперервний; який не минає, не залишає кого-небудь (про стан, почуття); 4) розрахований на довгий час, для тривалого функціонування; не тимчасовий; який є постійним атрибутом кого-, чого-небудь; завжди наявний, неодмінний. Сталі кадри - постійний склад працівників певної організації, установи, певного підприємства тощо; 5) який протягом тривалого часу не змінюють (про місце проживання, роботу, посаду, заняття); 6) твердий, непохитний; який надійно забезпечує існування, розвиток чого-небудь; остаточно визначений, сформований (про погляди, поняття тощо).

Стійкий - 1) здатний твердо стояти, триматися, не падаючи, не коливаючись; хисткий; який відбувається спокійно, розмірено; урівноважений; 2) який довго зберігає й виявляє свої властивості, не піддається руйнуванню, псуванню тощо; 3) для якого характерні стабільність, постійність; сталий; довготривалий; 4) здатний витримати зовнішній вплив, протидіяти чомусь; 
здатний зберігатися, існувати за несприятливих умов (наприклад, у разі зміни температури); витривалий; який не піддається сторонньому, негативному, впливу (про людину); 5) який виявляє наполегливість, твердість, непохитність у намірах, поглядах, вчинках, діях тощо; вірний своїм переконанням; незламний; який ведеться з наполегливістю, твердістю, непохитністю» [6].

В наших попередніх дослідженнях [7] ми визначили, що стійкість самоідентичності людини це концепція автентичного буття людини, яка передбачає спроможність діяти й відчувати відповідно до власного голосу Совісті. Становлення стійкості самоідентичності складається 3 формування самоідентичності й набуття її стійкості. Ці процеси відбуваються у внутрішньому просторі людини й потребують від неї певної дисципліни або, точніше - внутрішньої культури.

Період фрормування стійкості самоідентичності вимагає від людини усамітнення. Однак, сорормована стійкість самоідентичності потребує інших, щоб людина могла ствердитися в набутій стійкості самоідентичності. Отже в цій розвідці ми хочемо зосередитися на зовнішній культурі людини.

Ми припускаємо, що плідною точкою зіткнення людини з сфрормованою стійкістю самоідентичності і соціокультурного простору є саме зовнішня культура людини.

Поділ на внутрішню та зовнішню культуру особистості здається нам методологічно плідним і вже давно використовується (Біблер В. С., Гегель Г.В.Ф., Зіммель Г., Інгарден Р., Кант І., Кассірер Е., Межуєв В. М., Флоренський П.), хоча й не був достатньо концептуалізованим в філософії, у порівнянні, скажімо, до політології, де вже давно затвердилися поняття внутрішньої й зовнішньої політики.

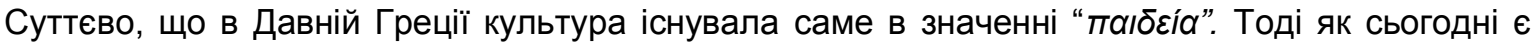
безліч визначень культури та її форм, в нашому дослідженні, ми прагнемо бути зосередженими саме на пайдеї, тобто культурі, яка невід'ємна від виховання.

Зазначимо, що І. Кант вважав, що «дисципліну слід відрізняти від культури, яка повинна тільки доставляти навички, не усуваючи інші, вже існуючі. Отже, для виховання таланту, який вже сам по собі схильний проявлятися, дисципліна має негативне, а культура і доктрина позитивне значення» [8, с. 291]. Тобто, на думку фрілософра, саме культура та теорія сприяють конструктивному розвитку людини.

І. Кант звертався до концептів “внутрішнє” й “зовнішнє” досліджуючи, насамперед, проблему гносеології. Оскільки наш розум створює внутрішнє почуття виходячи 3 того, що ми переживаємо, то воно постає як дещо зовнішнє, можливо, відмінне від нашого уявлення про нього, - замислювався фрілософ. І виходячи з цього, наголошував на особливій ролі нашого мислення, зокрема - спогляданні.

У спекулятивній фрілософії Г.В.Ф.Гегеля, зовнішнє знімається шляхом негації і перетворюється у внутрішнє. Внутрішнє Г.В.Ф. Гегель позначав яв “Innerlichkeit”, що означає “потаємна сутність”, “внутрішнє життя”, “душевність”, “щирість”. Тоді як для позначення зовнішнього фрілософ часто вживав слово “Ӓußerlichkeit”, яке перекладається як "формальне”, “показне", “побічне", "несуттєве”. Тобто, поняття “внутрішне" й "зовнішнє” філософ використовував насамперед як позначення глибини пізнання явища.

Разом з тим, коли Г.В.Ф. Гегель пише про рефлексію, йдеться, що «зовнішня або реальна рефлексія передбачає себе як зняту, як своє власне негативне» [9, с. 208]. Філософ зазначає, що «зовнішня рефлексія є висновок (Schlufi), в якому двома полюсами служать безпосереднє і рефлексія в себе» [9, с. 208]. Зрештою Г.В.Ф. Гегель приходить до висновку, що ця рефлексія $\epsilon$ визначаючою: «зовнішня рефлексія $€$ не зовнішня - пише філософр, а так само іманентна рефлексія самій безпосередності або те, що є через покладаючу рефрлексію, сутність в собі і для себе суща» [9, с. 208]. Таким чином, для фрілософра внутрішня рефлексія іманентна чистому буттю, тому її неможливо позначити, тоді як зовнішня рефлексія - стосується сутності і має відношення до світу явищ.

Отже, Г.В.Ф. Гегель розглядав спекулятивний характер внутрішнього та зовнішнього. При чому, “зовнішнє” в його фрілософії поставало як “показне”, а разом з тим і як єдине, реальне, що дане людині в явищах.

Втім, зовнішнє та внутрішнє є також і орієнтирами у просторі. Коли мова йде про культуру, спекулятивність може бути не в фокусі уваги. Адже можна говорити про культуру, яку людина розвиває в собі, виходячи виключно з особистих переконань. А можна говорити про культуру, яка розвивається в середовищі і $€$ зовнішньою по відношенню до людини. Втім, коли людина 
долучається до культури середовища, - виникає зовнішня культура людини. Адже вона при асиміляції стає водночас і культурою середовища і культурою людини, однак, стосовно місця виникнення і домінанти присутності, - залишається зовнішньою. Відтак, культуру людини можна розглядати як внутрішню і зовнішню культури.

Внутрішня культура людини, на відміну від особистої культури, є чимось інтимним і не завжди доступним для споглядання інших, результати її діяльності формують особистість. Внутрішня культура близька за змістом до самовиховання. Тоді як зовнішня культура - це вже створені кимось іншим норми і правила поведінки. Особистісна культура - завжди включає як зовнішню так і внутрішню. А культура людини взагалі - може мати за домінанту зовнішню або внутрішню культуру.

Артефрактом внутрішньої культури людини можна вважати «Сповідь» А. Августина, де філософ показує нам внутрішній рух його особистості до самовдосконалення. Прикладом зовнішньої культури людини може бути «Сповідь» Л. Толстого, де мислитель ділиться з нами досвідом свого залучення до християнської культури. Безумовно, це приклад прояву високої зовнішньої культури людини, коли її внутрішня культура настільки сильно розвинена, що надає зовнішній культурі людини особливої гамми інтерпретаційного характеру. Тож наведені приклади здаються близькими за змістом, втім, на нашу думку, канони християнства значно меншою мірою вплинули на особистість А. Августина ніж на Л. Толстого. Проблема полягає в тому, що має існувати культура залучення людини до культури середовища, як би це не звучало тавтологічно, однак ці соціальні практики сьогодні існують в стихійному вигляді і найбільше представлені в масовій культурі, яка при зверненні до неї людини, стає її зовнішньою культурою.

Можливо, більш вдалим прикладом зовнішньої культури особистості може бути «Татарська пустеля» Д. Буццаті. В цьому творі головний герой - Джовані Дрого долучився до зовнішньої культури, яка була притаманна спільноті фортеці. Він, так само як і решта військовослужбовців, захворів очікуванням війни, сподіванням здійснити подвиг і роками належно виконував свої обов'язки офріцера. Саме ці елементи його зовнішньої культури стають домінантними в його поведінці й світосприйнятті, він майже не продукував іншої, внутрішньої культури людини.

Власне, поділ на внутрішню та зовнішню культуру людини значимий саме задля загострення уваги на походженні культури й формування навику розрізнення свого та чужого, розроблення, насамперед, культури залучення людини до зовнішньої культури. Яка, на нашу думку, має містити потужний інтерпретаційний характер, як в «Сповіді» Л. Толстого.

Таким чином, ми зробили поділ культури людини на внутрішню й зовнішню. Внутрішня культура людини - це культура взаємодії з собою, заснована на індивідуальних переконаннях, яка має бути націлена на розвиток та вдосконалення себе. Тоді як зовнішня культура особистості - це культура взаємодії зі світом, яка передбачає долучення до загальної культури і має на меті збереження, розвиток та вдосконалення культурних надбань задля турботи про власний соціокультурний простір.

Слід зауважити, що “внутрішнє” та “зовнішнє” на рівні світосприйняття (І. Кант, Г.В.Ф. Гегель) теж значимі для людини зі стійкістю самоідентичності. Адже шукаючи себе, людина може надмірно захопитися своїм внутрішнім образом як, наприклад сталося з Пер Ґюнтом Г. Ібсена, який вважав, що був собою, а насправді тікав від себе справжнього, кидаючись у пошук місця, де в ньому розпізнали б царя (ідентифікували ззовні). Ця п'єса є наглядним прикладом того, що людина має працювати над собою, творити свою внутрішню культуру та приводити у відповідність до неї власну зовнішню культуру, а не лише керуватися своїм чуттям і шукати його підтвердження ззовні.

У розвитку внутрішньої культури людини в контексті формування стійкості самоідентичності, особливу роль відіграють такі елементи як тілесність, сексуальність, усвідомленість. Залучаючись до соціокультурного простору, людині необхідно продовжити розвивати ці якості для ствердження у стійкості самоідентичності. На рівні зовнішньої культури людини ці елементи представлені як відповідні соціокультурні практики: фрізичні вправи, спілкування з іншими, читання тощо. Отже розвиток зовнішньої культури людини передбачає ії залучення до соціокультурного простору. А доцільне використання практик соціокультурного простору веде до ствердження у стійкості самоідентичності людини й її сталого розвитку.

Соціокультурний простір - це «сконструйований кількома поколіннями простір сенсу, в якому відображена культурна специфріка соціальної організації досліджуваного соціуму» [10, с. 143]. 
Сучасний соціокультурний простір має ознаки планетарного, оскільки вміщає в себе безліч культур в різних пропорціях і завжди має до них доступ. Так, кожна людина може розвивати свою зовнішню культуру, звертаючись до будь яких культурних практик, які $€$ у відкритому доступі. Дослідження впливу окремих соціокультурних практик на розвиток стійкості самоідентичності потребує додаткових наукових розвідок.

Висновки. Для сталого розвитку демократичного суспільства необхідний сталий розвиток кожної людини цього суспільства. В основі сталого розвитку людини - їі стійкість самоідентичності. У формуванні стійкості самоідентичності людини особливу роль відіграють її внутрішня й зовнішня культури. Зовнішня культура людини розвивається в її соціокультурному просторі. За умови залучення людини до соціокультурних практик, які будуть допомагати їй стверджуватися у власній стійкості самоідентичності, - людина буде здатна проявляти сталий розвиток.

\section{Література}

1. Daly, Herman E. Ecological economics and sustainable development, selected essays of Herman Daly / Herman E. Daly. - MPG Books Ltd, Bodmin, Cornwall, - 2007. - 280 p.

2. United Nations. Sustainable Development Goals [Electronic resource] / Access mode: https://sdgs.un.org/goals.

3. Городецький, О. В. Філософія. Суспільство. Природа: навчально-методичний посібник для студентів, магістрів та аспірантів. / О. В. Городецький. - Дніпро : Видавництво ПФ «Стандарт-Сервіс», 2017. - 203 с.

4. Мартиненко, В. Про методологічний концепт формування та розвитку нової парадигми публічного управління та ї̈ понятійного апарату [Електронний ресурс] / В. Мартиненко. Режим доступу: http://ifs.kbuapa.kharkov.ua/e-book/putp/2012-4/doc/1/01.pdf.

5. Малахов В. А. Етика: Курс лекцій : навчальний посібник. / В. А. Малахов - 6-те вид. - К. : Либідь, 2006. - 384 с.

6. Вибір слова: довідник: для студ. спеціальності 061 «Журналістика» освітньої програми «Видавнича справа та редагування» [Електронний ресурс] / КПІ ім. Ігоря Сікорського; уклад. С. Б. Фіялка. - Електронні текстові дані (1 файл: 835 кБ). - Київ : КПІ ім. Ігоря Сікорського», 2019. - 446 с.

7. Пашинська, А. В. Стійкість самоідентичності в бутті людини / А. В. Пашинська // Наукові записки Національного університету «Острозька Академія». Серія філософрія. - 2017. - Вип. 20 (23-28). - С. 136-139.

8. Кант, И. Критика чистого разума / И. Кант. - М. : Мысль, 1994. -591 с.

9. Гегель, Г.В.Ф. Наука логики / Г.В.Ф. Гегель. - СПБ. : Наука, 1997. - 800 с.

10. Шакирова, Е. Ю. Общее представление о строении и динамике современного социокультурного пространства. Часть 2. / Е. Ю. Шакирова // Власть. - 2014. - № 2. - С. 143-146.

\section{References}

1. Daly, H. E. (2007). Ecological economics and sustainable development, selected essays of Herman Daly. Bodmin, Cornwall: MPG Books Ltd [in English].

2. United Nations. Sustainable Development Goals. www.sdgs.un.org. Retrieved from https://sdgs.un.org/goals [in English].

3. Horodetskyi, O. V. (2017). Filosofiia. Suspilstvo. Pryroda [Philosophy. Society. Nature]. Dnipro: «Standart-Servis» [in Ukrainian].

4. Martynenko, V. (n.d.). Pro metodolohichnyi kontsept formuvannia ta rozvytku novoi paradyhmy publichnoho upravlinnia ta yii poniatiinoho aparatu [The methodological concept of formation and development of a new paradigm of public administration and its conceptual apparatus]. www.ifs.kbuapa.kharkov.ua. Retrieved from http://ifs.kbuapa.kharkov.ua/e-book/putp/2012-4/doc/1/01.pdf [in Ukrainian].

5. Malakhov, V. A. (2006). Etyka: Kurs lektsii [Ethics: Lectures]. Kyiv: Lybid [in Ukrainian].

6. Fiialka, S. B. (2019). Vybir slova: dovidnyk [Choice of word]. Kyiv: KPI im. Ihoria Sikorskoho [in Ukrainian].

7. Pashynska, A. V. (2017). Stiikist samoidentychnosti $v$ butti liudyny [Sustainability of self-identity in human being]. Naukovi zapysky Natsionalnoho universytetu "Ostrozka Akademiia». Seriia filosofiia - Scientific notes of the National University "Ostroh Academy". Philosophy series, 20 (23-28), 136-139 [in Ukrainian].

8. Kant, I. (1994). Kritika chistogo razuma [Criticism of Pure Reason]. Moscow: Mysl [in Russian].

9. Hegel, G. W. F. (1997). Nauka logiki [Science of Logic]. Saint Petersburg: Nauka [in Russian].

10. Shakirova, E. Yu. (2014) Obshchee predstavlenie o stroenii i dinamike sovremennogo sotsiokulturnogo prostranstva. Chast 2 [General understanding of the structure and dynamics of modern sociocultural space. Part 2]. Vlast - Authority, 2, 143-146 [in Russian].

Надійшла 3.10.2019

Пашинська, А. В. Роль соціокультурного простору у формуванні стійкості самоідентичності людини / А. В. Пашинська // Проблеми соціальної роботи: філософія, психологія, соціологія. - 2019 - № 2 (14) - С. 71-76. 